\title{
The Pasture Quality Poster - a learning tool for farmers
}

\author{
W.E. PREWER and A. V. BYSTERVELDT \\ Dexcel, PB 3221, Hamilton \\ warwick.prewer@dexcel.co.nz
}

\begin{abstract}
The Dexcel "Feed4Profit" extension programme was established in 2001 to help dairy farmers increase their profitability through improved feeding systems. Managing for high pasture quality can result in increased milksolids production and profit. Dairy farmers learning needs around management of pasture quality were assessed at eight discussion groups throughout New Zealand. The farmers defined pasture quality more in visual than nutritional terms. They believed that it was dependent on soil fertility, quality and pasture cover and pasture composition. They grouped management into three main headings: day-today, periodic (spring and autumn - winter) and longterm. Day-to-day management included stocking rate, adequate pre- and post- grazing covers, round length, and use of inputs. Management during the spring included monitoring, harvesting supplements and topping. Autumn - winter management included regressing, weed control and minimizing pugging damage. Long-term management techniques included adequate soil fertility, drainage, selection of the appropriate breed of cow, and managing for persistence. Farmers identified that they needed to improve in their analysis and use of pasture quality information, management of different pasture species, management of surplus, low quality and low quantity pasture, and estimation of pasture quantity. The outcomes that the farmers wanted from their use of an extension package were increased pasture and land utilization, increased productivity and profitability. This research was used to develop an extension package around maintaining high pasture quality. A reference team of farmers and rural professionals guided the process. Their feedback resulted in a poster, rather than a booklet, being produced by the Feed4Profit team.
\end{abstract}

Keywords: dairy farmers, dairy management, extension, learning needs, milksolids, pasture quality, profit

\section{Introduction}

Research has shown that improving production per cow is a key strategy for improving profitability (Penno 1999; Macdonald et al. 2001). Offering cows high quality pasture can result in high dry matter intakes and more milk production than offering them pasture of lower quality. Stakelum \& Dillon (1991) reported an increase in milksolids production in the summer when cows grazed high quality pasture. Hoogendoorn et al. (1992) also reported a difference in production between cows grazing low and high quality pasture in the early spring and late spring/early summer.

Commercial and research farms have both demonstrated that the increase in production through management for high pasture quality can result in high farm profitability. Salles et al. (2003) reported that on twelve dairy farms in the southern North Island of New Zealand the provision of high allowances of high quality pasture helped maintain high levels of milk production. The average Economic Farm Surplus (EFS) per ha for the case study farms was approximately $43 \%$ higher than the top $24 \%$ farms in the Manawatu region. Farmlets containing the highest proportion of clover (and therefore likely to have had the highest pasture quality) also had the highest EFS per ha in the 2001/ 2002 season of the pasture cultivar trial (Woodward et al. 2003).

Pasture quality information can provide a basis from which feeding and pasture management strategies can be devised to enhance the nutrient value of pasture diets so that they might increase milk production (Muller 1993). However, there has been little research into the learning needs of dairy farmers about pasture quality. Crawford et al. (1995) reported that $13 \%$ of high performing farmers believed that they did not have complete or up to date technical knowledge about some aspects of management. They believed that this might have limited production on their farm. Farmers are generally aware of the importance of pasture quality, particularly in the spring-summer (Corson et al. 1999), but very few actually measure the quality of their pasture. They rely more on what is happening in the vat to tell them of any problems (Macintosh \& McNae 2001).

Research into the learning needs of sheep and beef farmers showed that they tend to look for component solutions to pasture quality problems e.g. seeking a trace element problem, use of tannin containing plants, regrassing, or growing forage crops. It is possible that focusing on such solutions distracts attention from low cost management tools that maintain pasture quality over the whole farm. Individuals within the groups interviewed generally did not have a have a clear picture regarding what were the most important components and how they inter-related (Lambert et al. 2000).

This paper discusses the process that was used to 
identify dairy farmer learning needs around pasture quality and develop and deliver a learning package to meet their needs. It must be noted that the main part of the delivery phase and the evaluation of the learning package occurred from August 2004 onwards, after this paper was written.

\section{Methods}

In 2001 consultation meetings with farmers and industry experts identified a farmer need for a better understanding of nutrition and feeding systems for dairy cows as a priority for extension. The extension programme "Feed4Profit" was initiated in August 2001 to meet this need. A reference team of farmers, researchers and private consultants was established to guide the programme team (Anon 2002). Since then the Feed4Profit programme has developed a range of learning packages to help farmers feed cows better to improve per cow performance and profitability. Examples include the Comparative Stocking Rate Handout (Speight 2002), the Feed Information Sheet (Anon 2003), FeedPlan (Prewer 2003), the Production Checklist (Anon 2003) and Seasonal Solutions for Improving Milk Production (www.dexcel.co.nz).

\section{What do farmers need to know and do?}

Increasing dry matter intake and improving pasture and feed quality will increase per cow milksolids production per cow. Given that a cow's diet in New Zealand comprises of $80-90 \%$ pasture, the focus of Feed4Profit was to help farmers improve the dry matter intake and quality of pasture. To develop an effective extension package around this topic farmer learning needs were assessed.

Dexcel Consulting Officers interviewed farmers at 8 discussion groups in the Waikato, the Waiarapa and the Nelson/Marlborough regions between February and December 2001. Farmers were asked about their understanding and management of pasture quality. An interview process similar to that used for assessing the learning needs of sheep and beef farmers for managing pasture quality (Lambert et al. 2000) was applied. The discussion was first framed up by exploring the links between improving profitability, production and pasture quantity and quality. Ideas were written on flipcharts and then collated. Open ended questions such as: "what do you need to know to improve milk production per cow?" and "how do you define pasture quality?" were used. Farmers were also asked about their desired outcomes.

Farmer responses are presented below verbatim in many cases, as understanding their ideas about pasture quality was thought to be the starting point for development of a user-friendly extension package. The farmers' concepts as recorded do not necessarily agree with those held by the authors.

\section{Results of learning needs analysis}

The farmers defined pasture quality in a variety of terms. Nutritional terms included digestibility, fibre/lignin, metabolisable energy, carbohydrate, crude protein, dry matter percentage and minerals. Visual terms included sunny days, pasture density, the proportion of fresh and dead grass, clover and ryegrass proportions, colour (dark green equals more protein and is better than light green), green all the way to the base, growth stage and seed head. Palatability and the presence of toxins were also terms used to define pasture quality.

The farmers believed that pasture quality was dependent on several factors: effluent applied to the paddock, soil fertility and quality, slope of the land, macro- and micro-nutrients (magnesium, calcium, zinc, etc.), lack of patches, cultivars, pasture composition, pasture cover ( $\mathrm{kg} \mathrm{DM} / \mathrm{ha})$. The ways in which the farmers managed pasture quality was grouped under three headings.

\section{Day to day}

This comprised stocking rate, pasture residuals (assessed by eye) and round length, "good grazing", adequate pregrazing covers, use of nitrogen and other fertilisers, rain and irrigation.

\section{Periodic}

The farmers divided this into two seasons. Spring comprised of monitoring, minimizing seed head, cutting for supplements, maintaining pasture species through regular management and topping in late spring. AutumnWinter consisted of maintaining pasture species through regrassing and selecting the right species, weed control by use of herbicides, different control for different species during specific periods and minimizing pugging damage by on-off grazing.

\section{Long-term or capital management}

This included adequate levels of fertility, lime and nitrogen, drainage, selection of appropriate breed of cow, management for persistence (pest management through harder grazing, reduced pulling, the age of the pastures, on-off grazing, management to suit the cultivar and minimizing pugging).

The farmers identified six topics in which they felt that they needed more knowledge, understanding and behaviour change:

1. How to analyse pasture quality and use the results to improve cow feeding production and profit?

2. How to manage different pasture species?

3. How to manage low quality and quantity pasture?

4. How to manage surpluses?

5. General pasture management (including nitrogen fertiliser use, target residuals, cost effectiveness of different types of pasture quality control).

6. Estimation of pasture quantity.

The outcomes that the farmers wanted from their use 
of an extension package around pasture quality were: increased pasture and land utilization, increased cow intakes, more milksolids production and more money.

\section{Development of the Pasture Quality Poster}

The learning needs analysis gave results similar to that found for sheep and beef farmers as reported by Lambert et al. (2000). The dairy farmers interviewed had a good grasp of what pasture quality was, what it was influenced by and how to manage it. However they lacked knowledge and understanding of the relationships between profit, production and pasture quality. The farmers viewed pasture quality management in seasonal (mainly spring, summer and winter) and visual (colour of pasture, species composition, growth stage, quantity of pasture) terms. Anecdotal evidence suggested that dairy farmers lacked the motivation to manage pasture well for high feed quality. This showed that an effective extension package around managing for high quality pasture was needed. The objective of the package was to "motivate and help farmers to improve their pasture management skills, enabling them to maintain a high pasture quality throughout the season".

The Feed4Profit team started designing the extension package in autumn 2002. The extension package consisted of handouts, facilitators notes, flipcharts and visual aids that would be delivered to farmers by Dexcel Extension staff and rural professionals at discussion groups and field days around New Zealand from September 2002 to December 2002 and via the Dexcel website. A booklet was chosen to be a major part of the extension package, due to the success of a similar booklet "Fertiliser Use on New Zealand Dairy Farms” (Roberts \& Morton 1999). It was envisaged that it would summarise:

- The importance of high quality pasture for increased intake by dairy cows

- The impact of pasture quality on milk production

- The role of fertiliser, topping, surplus conservation, grazing residuals and pasture composition in maintaining high quality pasture

Work started on the booklet in October 2002. Key sources included Brander \& Matthews (1997), Cassells \& Matthews (1995), Fulkerson \& Donaghy (2001), Hoogendoorn et al. (1992), Holmes et a.l (2002), Kolver (2000), Kolver et al. (1999) Matthews (1995), Matthews et al. (2002) and Thomson \& Hainsworth (1997). The Feed4Profit reference team reviewed the draft material in March 2003. Their feedback resulted in changing the format from a booklet to a poster, for the following reasons:

- Farmers and rural professionals preferred a poster to a booklet

- Farmers find a poster easier to read, and it is easy to distribute
- The success of a product (The Feed4Profit Feed Information Sheet) released in February 2003 suggested that farmers liked poster-type products.

The material was then re-organised and summarised as the following main principles:

1. Definition of high quality pasture

2. How to assess pasture quality

3. Relationship between the vegetative growth of grass and rotation length

4. Nutritive value of pasture and the effect of higher pasture quality on milk production

5. Effects of pre-grazing pasture mass and post-grazing residual mass on energy intake, cow performance and pasture regrowth

6. Definition of optimum post-grazing residual for high quality pasture and high feed intakes

7. Calculations for deciding which paddocks to take out for conservation of surplus pasture

8. Key seasonal focus points

The reference team reviewed a draft version of the poster in October 2003. Their suggestions were incorporated into the final version of the poster, which was then designed and printed. A copy of the final product can be obtained from your local Dexcel Consulting Officer.

\section{Delivery of the Pasture Quality Poster}

Since spring (September - November) is the most important time to be managing pasture quality, application of the poster information is likely to be greatest if it is promoted strongly in spring. As the poster was printed in November 2003, it was to decided to stagger its promotion and delivery over the next 12 months, with a large promotion in Spring 2004. To date about 3200 copies of the poster have been released to rural professionals for delivery to farmers. Initial farmer response to the poster has been positive. Evaluation of the impact of the learning package on dairy farmers is scheduled for June 2005.

Lessons learnt for developing a learning package for dairy farmers

1. Market research highlighted the learning needs of farmers, but should also have identified the best delivery mediums (e.g. booklet, poster, workshops).

2. A market scan of similar products helped identify gaps in current material that the learning package could fulfil, and expertise that could advise on its development.

3. Continual input and reviewing by a reference team of farmers and industry experts ensured that the learning package was "farmer friendly" and technically sound.

4. A flexible approach is needed in developing the package. The change from producing a booklet to a 
poster is not a failure but a success in listening to our clients - farmers.

5. Recipients of the learning package will be identified and tracked to allow a proper evaluation of the success of the project.

\section{ACKNOWLEDGEMENTS}

The Feed4Profit team gratefully acknowledges funding from Dairy InSight and the Ellett Agricultural Research Trust.

\section{REFERENCES}

Anonymous 2002. Feed4Profit extension programme. Dairy Exporter, May 2002: 108- 109.

Anonymous 2003. Production Checklist (Insert sheet). Dexcelink. December 2003.

Anonymous 2003. Feed Information Sheet (Insert sheet). Dexcelink. March 2003.

Brander, S.; Matthews, P. 1997. Feeding practices: Recent changes in attitude, their reason and effect - a case study. Massey Dairy Farming Annual 49: 7276.

Cassells, B.; Matthews, P. 1995. Experiences in improving production by the use of supplements. Massey Dairy Farming Annual 47: 40- 45.

Corson, D.C.; Waghorn, G.C.; Ulyatt, M.J.; Lee, J. 1999. NIRS: Forage analysis and livestock feeding. Proceedings of the New Zealand Grassland Association 61: 127-132.

Fulkerson, W.J.; Donaghy, D.J. 2001. Plant soluble carbohydrate reserves and senescence - key criteria for developing an effective grazing management system for ryegrass-based pastures: a review. Australian Journal of Experimental Agriculture 41: 261-275.

Holmes, C.W.; Brookes, I.M.; Garrick, D.J. Mackenzie, D.D.S.; Parkinson, T.J.; Wilson, G.F. 2002. Milk Production from Pasture. Massey University.

Hoogendoorn, C.J.; Holmes, C.W.; Chu, A.C.P. 1992. Some effects of herbage composition, as influenced by previous grazing management on milk production by cows grazing on ryegrass/ white clover pastures. 1. Milk production in late spring/summer: effects of grazing intensity during the preceding spring period. Grass and Forage Science 47: 316-325.

Kolver, E. S. 2000. Nutrition guidelines for the high producing cow. Proceedings of the Ruakura Dairy Farmers' Conference 52: 17- 28.

Kolver, E. S.; Penno, J.W.; Macdonald, K. A.; McGrath,
J.M.; Carter, W.A. 1999. Mowing pasture to improve milk production. Proceedings of the New Zealand Grassland Association 61: 139-145.

Lambert, M.G.; Paine, M.S.; Sheath, G.W.; Webby, R.W.; Litherland, A.J.; Fraser, T.J.; Stevens, D.R. 2000. How do sheep and beef farmers manage pasture quality? Proceedings of the New Zealand Grassland Association 62: 117-121.

Macdonald, K.A.; Penno, J.W.; Nicholas, P.K.; Lile, J.A.; Coulter, M.; Lancaster, J.A.S. 2001. Farm systems - Impact of stocking rate on dairy farm efficiency. Proceedings of the New Zealand Grassland Association 63: 223-227.

Macintosh, M.; McNae, D. 2001. Visual pasture quality assessment: Why and How? Massey Dairy Farming Annual 53: 97- 104.

Matthews, P. 1995. Grazing management principles and targets. Massey Dairy Farming Annual 47: 171- 174.

Matthews, P.; Hughes, F.; Salles, P.; Phillips, R. 2002. Production and financial evaluation of the Agmardt dairy farm monitoring project. Massey Dairy Farming Annual 54: 65- 74.

Muller, L.D. 1993. Nutritional supplementation and ration balancing for high producing cows. pp. 71-80. In: Improving the quality and intake of pasture-based diets for lactating dairy cows. Eds. Edwards, N.J.; Parker, W.J. Occasional Publication No. 1, Department of Agricultural and Horticultural Systems Management, Massey University, Palmerston North.

Penno, J.W. 1999. Stocking rate for optimum profit. Proceedings of the South Island Dairy Event: 25- 43.

Prewer, W.E. 2003. Dexcel Feed4Profit FeedPlan: A Software Tool For Feed Budgeting. Proceedings of the Dairy ${ }^{3}$ Conference 1: 193-196.

Roberts, A. H.C.; Morton, J.D. 1999. Fertiliser Use on New Zealand Dairy Farms. New Zealand Fertiliser Manufacturers' Association.

Speight, S. 2002. A smarter way of looking at stocking rate. Proceedings of the Ruakura Dairy Farmers' Conference 54: 6-8.

Stakelum, G.; Dillon, P. 1991. Influence of sward structure and digestibility on the intake and performance of lactating and growing cattle. pp. 30-44. In: Management Issues for the Grassland Farmer in the 1990s. Ed. Mayne, C.S.

Thomson, N. A; Hainsworth, R. 1997. Identifying a feed surplus. Proceedings of the Ruakura Dairy Farmers' Conference 49: 100- 105. 